\author{
Military Technical College \\ Kobry El-Kobbah, \\ Cairo, Egypt.
}

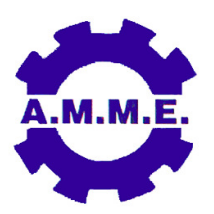

$17^{\text {th }}$ International Conference
on Applied Mechanics and
Mechanical Engineering.

\title{
INVESTIGATION THE CRITICAL SUCCESS FACTORS OF TQM CRITERIA IN THE INDUSTRIAL ORGANIZATIONS
}

\author{
N. Sobhi ${ }^{1}$, S. A. Salah ${ }^{2}$ and E. Magdy ${ }^{3}$
}

\begin{abstract}
Total quality management is a philosophy of management for continuously improving the quality of products and processes. The quality of products and processes is the responsibility of everyone who is involved with the development or use of the products or services.

TQM implementation provides people with opportunities to learn and to develop themselves. TQM enables all employees to participate in the continuous improvement process to improve the organizational performance and assure customer's satisfaction. A company that is able to assess and understand its TQM success factors can focus on improving its performance. This paper investigates the critical success factors of TQM criteria in the industrial organizations, which had achieved the certificate of the quality management system (ISO 9001). This paper used a questionnaire survey method to assess the actual level of implementation of the TQM systems in the organizations. The results of the data analysis identified eight factors that affect companies' performance; leadership; customer focus; involvement of people; process approach; continuous improvement; supplier relationship; decision-making and communication. The results indicate that the successful implementation of total quality criteria in the industrial organizations leads to a significant increasing in the performance and business environment.
\end{abstract}

\section{KEY WORDS}

Quality management systems, TQM critical success factors, organizational performance.

1 Professor Dr., Dean of Faculty of Engineering, October University for Modern Science and Arts, Cairo, Egypt. nahed.sobhi@gmail.com.

2 Dr., Dpt. of Industrial Engineering, October University for Modern Science and Arts, Cairo, Egypt. Sameh1164@yahoo.com.

3 Eng., Dpt. of Design and Production Engineering, Ain Shams University, Cairo, Egypt. 


\section{INTRODUCTION}

Total quality management is about measurement and evaluation. The only way to know if improvement is taking place is by measuring current performance and comparing it with the benchmarks. TQM is a tool to integrate fundamental management techniques, existing improvement efforts and technical tools under a disciplined approach focused on continuous improvement. TQM involves management, workforce, suppliers, and even customers, in order to meet or exceed customer expectations.

International organization of standards (ISO) consists of global federation of 130 national standards countries have the same aim of promoting standardization and the development of related activities. They cooperated in the sphere of intellectual, scientific, technological and economic activities to facilitate the international exchange of goods and services. The ISO 9000 standard series is now widely accepted as a minimum standard for a quality system for companies [1]. The possession of a certification to ISO 9000 has become a decisive competitiveness factor in the international market. Business relationships are increasingly influenced by the possession of an ISO 9000 certificate which proves to have an important advertising effect. Additionally the consequent application of an ISO 9000 system can have a significant cost reduction affect which results in performance improvement [2].

TQM and productivity have become major concerns of business managers seeking to maintain or increase competitive advantage. At present dynamic manufacturing environment, where quality is vital to success, manufacturers use TQM as a tool to substantially improve productivity and customer satisfaction. Besides, most of the previous studies point out that productivity is one of the measure performances directly affected by application of the TQM principles.

\section{INTEGRATION OF QUALITY MANAGEMENT SYSTEM AND TQM}

\section{ISO 9001}

ISO 9001 application is a factor that increases employee motivation and operational efficiency, then provide stability and consistency to business life [3]. In today's globally competitive environment, started the creation of an integrated quality management systems for the product, system and the personal certification process, ahead of these standards, criteria such as environment, health and safety have been included. Satisfy and motivate the employees seen as internal customers depends on providing continuous technical training in companies which are implementing ISO 9000 QMS in the context of TQM as shown in figure 1 [4]. Meanwhile, adoption of the importance of their work is very important for employees.

\section{TQM}

TQM is related to competitiveness of enterprises gained and main purpose is high efficiency, product and market differentiation, high quality, low cost and achieves the 


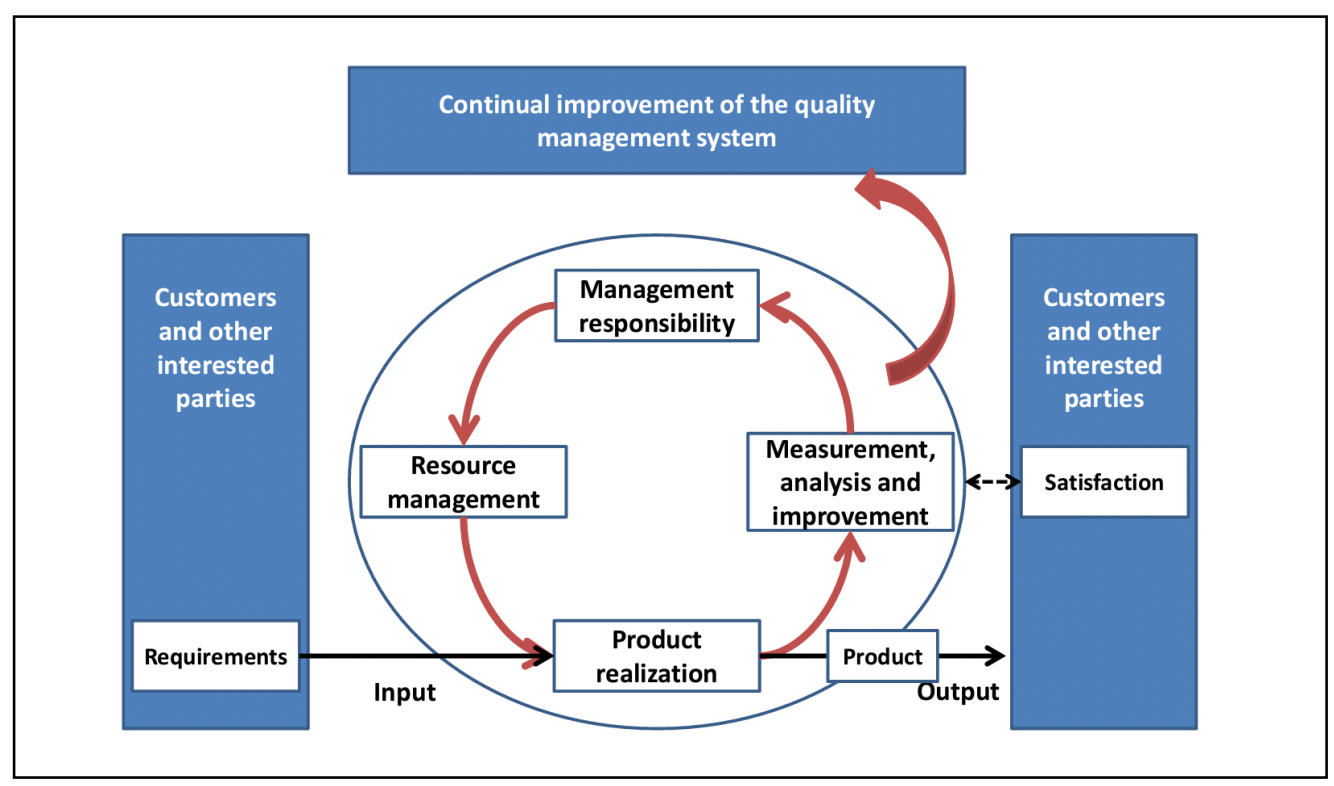

Fig. 1. ISO 9000 certification-QMS [4].

high competitiveness power. TQM is truly generic as it can be implemented in both manufacturing and service sectors and despite their different natures; they face similar problems in realizing the full benefits of TQM [5] as shown in figure 2. The implementation of quality programs is gaining acceptance as a way of maintaining a competitive edge, of simply surviving in fiercely competitive market or increasing performance and productivity. From this perspective, product development or service improvement and cost reduction is imperative [6].

The adoption of TQM concepts leads to inspiring employees to succeed and grow themselves and, then improving their performance and productivity [7].

There is a growing body of empirical research supporting a direct relationship between the adoption of TQM and improved performance. TQM leads to sustainability of advantage. TQM provides a unifying framework that brings a range of "good management practices" to bear simultaneously. As already pointed out, there is agreement among Crosby, Deming, Feigenbaum, Ishikawa, and Juran that the purpose of quality management is to reduce costs and improve satisfaction. In TQM approach, it is essential that company owners, dealers and suppliers, employees and customers are to be satisfied at the same time and loyal to the firm. Nilsson [8] has been conducted a cross-cultural quality management study of 12 countries, in Sweden with a sample of Swedish firms. He found that US, Japan, and Sweden having the same high level with respect to their cultural approach toward quality management.

The implementation of TQM leads to superior performance in business results, client satisfaction, employee satisfaction and social impact, leadership, strategic planning, customer and market focus, information and analysis, human resource focus, process management and business results. Benefits of TQM implementation included greater customer satisfaction, increased productivity of personnel and enhanced quality of services and products [9]. 


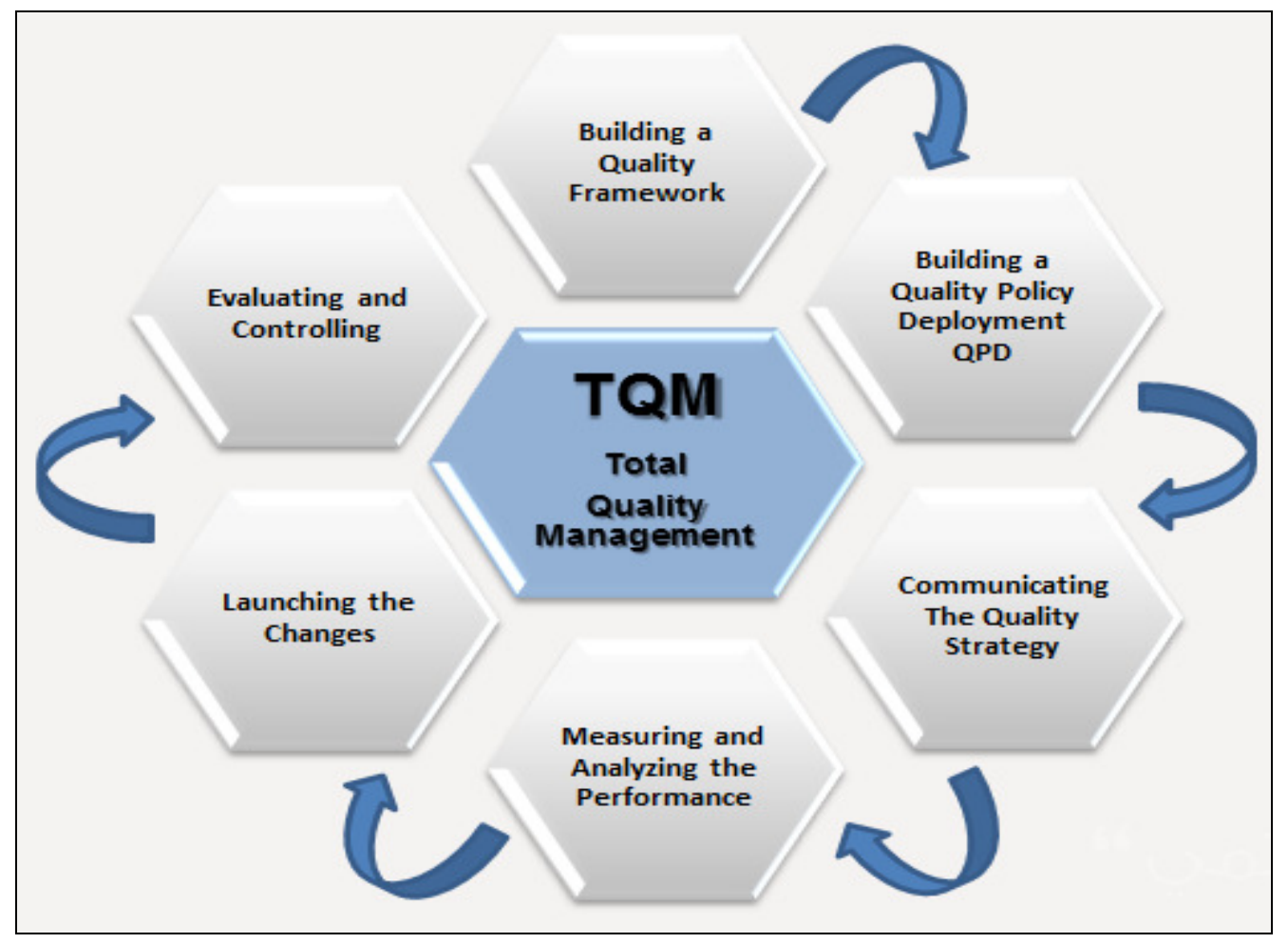

Fig. 2. TQM in an organization [5].

\section{Organizational Performance}

A large number of factors affects organizational performance. TQM practices have a positive effect on performance [10]. Performance strategy sometimes head off in the wrong or inappropriate ways. This happened because members are not entirely clear about what they are supposed to do or satisfy, under TQM.

Performance defined as the point of an individual, group or organization's pre-set objectives reached both qualitative and quantitative. Employees beginning from arrival to business, they use their knowledge and skills within the framework of job description and in return for gathering social and economic advantages within the business opportunities.

In this context, we can say that organizations' high or low performance depends on employees' individual performance level [11] as shown in figure 3. The concept of performance in business is an issue due to several factors. Such as, Realistic organizational goals, explaining the objectives to employees, overlap individual purposes with organizational objectives.

The business performance is most directly affected by the implementation of TQM principles [12]. This indicates that adopters of TQM have achieved success in both their operational and financial results. One of the most important expected relationships is that between the implementation of TQM elements and organizational performance. 


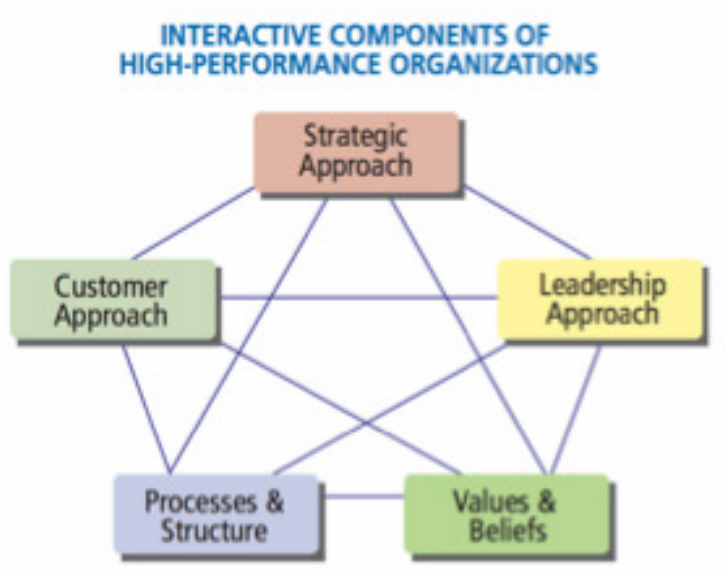

Fig. 3. Organizational performance [11].

\section{Impact of TQM and ISO 9001}

Many Studies have been conducted by scholars and analyzed the impact of TQM and ISO 9000 certification on the companies' performance. The obtained results indicated that the organizational performance increases with implementation of TQM and ISO 9000. TQM has an effect, which increases the socio psychological motivation on employees and organizational-managerial motivation [13], compared the joint effects of TQM and ISO 9001, and agrees in pointing out that TQM implementation leads to better results in more aspects than ISO 9001 certification. However, one of the benefits attributable to the standard is that it constitutes a good first step towards a TQM system, raising awareness on quality amongst workers and creating a good climate to implement it. Gotzamani [14] Affirm that the ISO 9001 certification has more impact on company performance when it is implemented with the objective of continuing and finally implementing a TQM system. It is important to point out that the TQM dimensions that best influence companies' results (the soft variables) are those that have a lesser weight in ISO 9001. Moreover, the criteria of TQM are more important for ISO 9001.

\section{TQM Critical Success Factors}

Thomas [15] examined the development of TQM practices in 22 manufacturing and service organizations in Spanish and developed eight of critical success factors of TQM. He found that the successful implementation of TQM appears to critically depend on certain tactics, behavior, features e.g. top management commitment; effective communications; employee involvement and less upon such TQM tools and techniques as training in quality; flexibility in manufacturing; process management, benchmarking and performance measurement.

A study investigating the implementation of TQM in Turkish manufacturing organizations showed that factors, including: upper management support; employee involvement and commitment; customer focus; quality education and training, 
teamwork and use of statistical techniques are the factors that successfully contribute to the TQM efforts [15].

Michael [16] investigating the success of TQM implementation in a service sector in Iran and concluded that for TQM to be successful, factors including top management commitment to quality and involvement; top management stability; strategic quality planning for quality; employee involvement; a team work and quality culture; focus on customers (internal and external); open communications; management by fact to solve problems; continuous improvement; aligning process to improve customer satisfaction; focus on supplier and partners and monitoring and evaluation of quality are critical success factors of TQM.

Abdullah [17] identified the soft factors that can influence the quality improvement practices and organizational performance in Malaysian manufacturing companies. These included management commitment, customer focus, employee involvement, training, education, reward, and recognition. More recently, [6] identified 24 success factors of TQM implementation in Qatari industrial sector and classified them into strategic, tactical and operational factors. The strategic factors are, top management commitment, continuous improvement and benchmarking, and dominating factors, which, play a significant role in the success of TQM implementation. The tactical factors, such as, employee training and involvement and empowerment, team building and problem solving, use of IT to collect and analysis data and supplier quality and relationships are the factors that impact the methods and actions employed in accomplishing the expected benefits of TQM implementation. The operational factors, such as, management of customer relationships, process control, resource conversation and utilization, and enterprise performance metrics for TQM, and the factors that produce visible consequences in a short period. These success factors should be implemented holistically rather than on a piecemeal basis to get the full potential of the TQM.

TQM is shown here as a management system that requires top management commitment to focus on customer satisfaction as the ultimate goal by improving the organizations process management. This involves all its employee and suppliers using continuous improvement as its basis. Essential to the ideology of TQM is the conception that quality is fundamental to all processes of business, not only manufacturing processes. Companies keen to adopt TQM principles should aim for quality improvement techniques in almost every stage of product improvement, manufacturing, distribution, administration and customer service. To evaluate TQM criterion, substitute variables have to be used such as "effective communication with customers", "seeking and learning customers' needs", "the recognition of key customer requirements", etc. these variables are expressions of "customer focus". To carry out a field study, each variable would need to be measured with an item in a scale. These items incorporated in the scale should satisfactory span the scope of the construct for content validity. 


\section{WORK DESIGN AND METHODOLOGY}

\section{TQM Criteria}

This study has been investigated eight criteria of TQM for improving the organizational performance from study the literature review as follows:

1. Leadership: Leaders establish unity of purpose and direction of the organization. They should create and maintain the internal environment in which people become fully involved in achieving the organization's objectives. This element as measured by a number of items related to top management involvement in establishing and communicating the organization's vision, goals, plans and values for its quality program, the role of leadership in anticipating and accommodating change, in maintaining the accuracy and reliability of all information and communications within the organization, in allocating adequate resources towards continuous improvement, in viewing the quality mind-set among managers, in having faith, trust and confidence in managers and whether the evaluating of leadership is based on quality performance, in pursing long term business success and in making quality responsibility accepted among all the organization's departments.

2. Customer focus: Organizations depend on their customers and therefore should understand current and future customer needs, should meet customer requirements and strive to exceed customer expectations. This element was measured through the subset of items on: the product/service development base and the needs of the customer, communication mechanisms with customers, seeking mechanisms to learn of the customers' needs and expectations, the identification of key customer requirements, the availability of mechanisms to deal with complaints and to provide guidelines to customers, the supply of customer care training, measuring customer satisfaction, reviewing customer-focused strategies and approaches, the focus on after sales strategies and customer relationships and partnerships in the company.

3. Involvement of people: People at all levels are the essence of an organization and their full involvement enables their abilities to be used for the organization's benefit. This element was measured through the subset of items on: the effectiveness of selection and recruitment process, the emphasis of promotion and career development programs, understanding the concept of the "internal customer", the openness of communication, the establishment of training programs that cover all aspects of TQM, the periodic assessment of training needs, the implementation of periodic quality activities, measuring employee satisfaction, employees responsibility to quality, the use of the team approach for solving problems, recognizing and rewarding employees.

4. Process approach: A desired result is achieved more efficiently when activities and related resources are managed as a process. This element was measured through the subset of items on: clean appearance of the work place, 
performing maintenance plans for product equipment, using SPC for process control and improvement, the extent to which a process design is "fool-proof", conducting systematic benchmarking of other companies business performance and standardizing and documenting operating procedures.

5. Continuous improvement: Continuous improvement of the organization's overall performance should be a permanent objective of the organization. This element was measured through the subset of items on: the encouragement for continuous improvement of all products, services and processes, the measurement of product and process quality, having a program aimed at finding time and cost losses in all internal processes, using the seven QC tools and PDCA cycle extensively for process control and improvement, using objective data as the basis for quality improvement and viewing evaluation as a requirement for improvement not for criticism.

6. Supplier relationship: An organization and its suppliers are interdependent and a mutually beneficial relationship enhances the ability of both to create value. This element was measured through the subset of items on: the establishment of long-term co-operative relations with suppliers, the most important factor for selecting suppliers, participation in supplier activities related to quality, giving feedback on the performance of suppliers' products, keeping detailed information about supplier performance and the reliance on few dependable suppliers.

7. Decision making: Effective decisions are based on the analysis of data and information. This element was measured through the subset of items on: the organization's team member opinions, ideas for solving the problems and sessions to get all ideas to solve these problems.

8. Communication: Communications in a quality environment may need to be addressed differently in order to communicate to all employees a sincere commitment to change. This element was measured through the subset of items on: the communication channels between employees and managers, feedback on ideas and issues, discussing problems and these ideas.

\section{Data Preparation and Collection}

The questionnaire was investigated and designed according to the eight TQM criteria, such that, every group of questions expresses the presence of one TQM criteria. The Five-point Likert scale, which is the most commonly used tool for this purpose, was utilized to identify a range of responses within the questionnaire. The questionnaire was hand delivered for the quality departments in 75 companies. Only 40 questionnaires were received from 40 companies. All the 40 companies have achieved the certification of (ISO 9001). The responses of the 40 participating companies were classified into two groups: one for the companies that applied a TQM (19 companies) and the second for those are not applied a TQM (21 companies). Although the questionnaire used in this study is self-administered, there was, in most case, interaction between the respondent and the interviewer. This was 
done to ensure control over the way in which the questionnaire was answered and to avoid ambiguity.

\section{Data Analysis Methods}

After collecting the data, the responses were coded and entered into SPSS 17 for data analysis. Regardless of which TQMS criteria are adopted, these criteria must be operated for empirical study. This includes the selection of a list of questions to measure each criterion, providing a measurement scale for the items and then examining the instrument for reliability.

\section{RESULTS AND DISCUSSION}

- The obtained results were analyzed with the aim of assessing the existing TQM criteria in manufacturing companies. A company that is able to assess and understand its TQMS can focus on improving its performance. The analyzed data that was collected using the questionnaire will be presented and summarized in Table 1.

- The reliability analysis provides information about the relationships between individual items (statements) in the scale. The obtained results of reliability test which uses Cronbach alphas indicated that, the coefficient alpha's for all eight criteria is greater than 0.70 , then, it is considered to be internally consistent.

- The obtained results show that, the mean score of each item ranges from 3.18 to 3.71 , which represent a considerably good results for the importance of adopting the eight TQM criteria in the organizations to increase the performance.

- The obtained results from the independent samples T-Test and ANOVA for TQM criteria within companies applies TQM and those are not applied, shows that, the mean of companies that applied TQM is larger than the mean of the companies that are not applied TQM. The results mean that there is a significant difference between applying TQM and not applying TQM as shown in Table 2.

- The obtained results from Simple regression analysis (as we have one independent variable) are used to determine the relationship between TQM score (applied TQM or not (dependent variable)) and each of the eight measurement scales (8 TQM principles (independent variable)). TQM score is regressed against the eight measurement scales.

- All the independent variables (eight TQM criteria) have significant positive correlations with the dependent variable (TQM Score) as shown in Table 3.

- Since the coefficient of determination (R2) is the ratio of the explained variation to the total variation. It explains the variation in the dependent variable due to the variation in the independent variable. From table 3 , the coefficient of determination (R2) for "Customer focus" has the highest ratio (77.3\%), thus the "Customer focus" can explain approximately $77 \%$ of the change in organization performance. It can, also, see that the lowest ratio is $34.2 \%$ for "Supplier relationship". This means that "Supplier relationship" can explain approximately $34 \%$ of the change in organization performance. 
- Since the coefficient of regression tells how much the dependent variable is expected to increase (if the coefficient is positive) or decrease (if the coefficient is negative) when that independent variable increases by one. From table 3, all the eight coefficient of regression are positive, then the dependent variable (TQM Scores) is expected to increase due to applying TQM criteria. The highest coefficient of regression is 0.729 for "Involvement of people" and 0.725 for "Customer Focus". The lowest value 0.401 is for "supplier relationship".

Table 1. Descriptive analysis of the Eight TQM principals.

\begin{tabular}{|c|c|c|c|c|c|}
\hline TQM criteria & $\begin{array}{c}\text { No. of } \\
\text { Question }\end{array}$ & Mean & $\begin{array}{c}\text { Standard } \\
\text { deviation }\end{array}$ & $\begin{array}{c}\text { C.V. } \\
\text { (Coefficient } \\
\text { of } \\
\text { variation) }\end{array}$ & $\begin{array}{c}\text { Cronbach's } \\
\text { Alpha }\end{array}$ \\
\hline Leadership & 12 & 3.4 & 1.2 & 34.7 & 0.935 \\
\hline $\begin{array}{c}\text { Customer focus } \\
\text { Involvement of } \\
\text { people }\end{array}$ & 14 & 3.5 & 1.2 & 35.1 & 0.904 \\
\hline Process approach & 8 & 3.7 & 1.0 & 29.2 & 0.870 \\
\hline $\begin{array}{c}\text { Continuous } \\
\text { improvement }\end{array}$ & 12 & 3.6 & 1.2 & 33.7 & 0.895 \\
\hline $\begin{array}{c}\text { Supplier } \\
\text { relationship }\end{array}$ & 5 & 3.3 & 1.4 & 43.4 & 0.750 \\
\hline Decision making & 3 & 3.2 & 1.2 & 40.5 & 0.816 \\
\hline Communication & 7 & 3.4 & 1.2 & 35.7 & 0.881 \\
\hline
\end{tabular}

Table 2. Independent samples T-Test - ANOVA and Eta results for TQM criteria.

\begin{tabular}{|l|l|l|l|l|l|c|}
\hline \multicolumn{1}{|c|}{ TQM criteria } & $\begin{array}{c}\boldsymbol{\mu} \\
\text { applied } \\
\text { TQM }\end{array}$ & $\begin{array}{c}\boldsymbol{\mu} \text { not } \\
\text { applied } \\
\text { TQM }\end{array}$ & t cal & $\begin{array}{c}\text { P- } \\
\text { value }\end{array}$ & Eta & $\begin{array}{c}\text { Result } \\
(\mathbf{\alpha = 0 . 0 5 )}\end{array}$ \\
\hline Grand mean & 4.12 & 2.931 & 11.006 & 0.000 & 0.872 & Sig. \\
\hline Leadership & 3.145 & 2.813 & 7.738 & 0.000 & 0.774 & Sig. \\
\hline Customer focus & 4.241 & 2.898 & 8.938 & 0.000 & 0.833 & Sig. \\
\hline $\begin{array}{l}\text { Involvement of } \\
\text { people }\end{array}$ & 4.205 & 3.252 & 5.279 & 0.000 & 0.662 & Sig. \\
\hline Process approach & 4.243 & 3.107 & 5.532 & 0.000 & 0.668 & Sig. \\
\hline $\begin{array}{l}\text { Continuous } \\
\text { improvement }\end{array}$ & 4.206 & 3.052 & 6.066 & 0.000 & 0.711 & Sig. \\
\hline Supplier relationship & 3.99 & 2.62 & 7.851 & 0.000 & 0.787 & Sig. \\
\hline Decision making & 3.877 & 2.556 & 5.239 & 0.000 & 0.648 & Sig. \\
\hline Communication & 4.015 & 2.878 & 6.066 & 0.000 & 0.635 & Sig. \\
\hline
\end{tabular}


Table 3. Regression Models with Total TQM Score as a Dependent Variable.

\begin{tabular}{|c|c|c|c|c|c|c|c|}
\hline \multirow{2}{*}{ 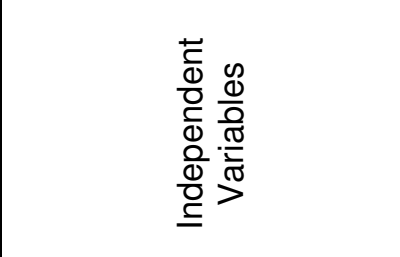 } & \multicolumn{2}{|c|}{$\begin{array}{c}\text { Analysis of } \\
\text { Variance }\end{array}$} & \multirow{2}{*}{ 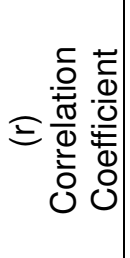 } & \multirow{2}{*}{ 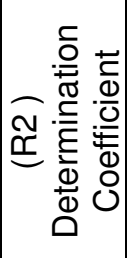 } & \multirow{2}{*}{ 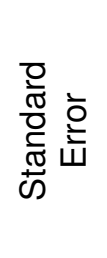 } & \multirow{2}{*}{ 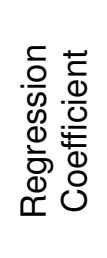 } & \multirow{2}{*}{ 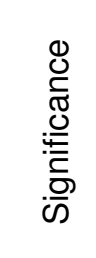 } \\
\hline & เ' $\stackrel{\frac{0}{\pi}}{\frac{\pi}{>}}$ & 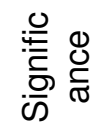 & & & & & \\
\hline Leadership & 法 & 0.000 & 0.791 & 0.626 & 0.416 & 0.611 & 0.000 \\
\hline Customer Focus & 129.193 & 0.000 & 0.879 & 0.773 & 0.325 & 0.725 & 0.000 \\
\hline Involvement Of People & 62.635 & 0.000 & 0789 & 0.622 & 0.418 & 0.729 & 0.000 \\
\hline Process Approach & 66.682 & 0.000 & 0.798 & 0.637 & 0.416 & 0.623 & 0.000 \\
\hline Continuous Improveme & 61.968 & 0.000 & 0.787 & 0.620 & 0.420 & 0.644 & 0.000 \\
\hline Supplier Relationship & 20.091 & 0.000 & 0.588 & 0.347 & 0.551 & 0.401 & 0.000 \\
\hline Decision Making & 64.900 & 0.000 & 0.794 & 0.630 & 0.414 & 0.517 & 0.000 \\
\hline Communication & 44.141 & 0.000 & 0.733 & 0.537 & 0.463 & 0.544 & 0.000 \\
\hline
\end{tabular}

\section{CONCLUSION}

- The questionnaire method is reliable and valid to measure the degree of implementation of the eight TQM criteria in the organizations.

- The implementation of the TQM criteria in the organizations has a great impact in improving the organizational performance and there is a significant difference between applied and not applied TQM criteria companies.

- There is a significant correlation between applied applied and not applied TQM companies and the eight TQM criteria.

- The eight critical success factors of the TQM criteria are important criteria in the industrial organizations in order to have the full benefit of TQM implementation and improve the organizational performance.

\section{REFERENCES}

[1] Chin, K. S., Tummala, V. M. R., 2003, "Quality management practices in Hong Kong industries: A comparison between electronics and toys manufacturing industries", International Journal of Quality \& Reliability Management 20(9).

[2] Rodriquez, C. and Hemsworth, D., 2005, "A Structural analysis of the impact of quality management practices in purchasing on purchasing and business performance", Total Quality Management and Business Excellence, 16(2), 215-230.

[3] Magd, H., \& Curry, A., 2003. "An empirical analysis of management attitudes towards ISO 9001:2000 in Egypt", TQM Mag., 15(6), 381-390.

[4] Ersen, H., 2003, "A total perfection in the process, human resources and quality", 2nd Edition, Istanbul.

[5] Yatkin, A., 2004, "Total Quality Management”, Ankara: Nobel Publications. 
[6] Al-Khalifa, K. N. and Aspinwall, E. M., 2000, "The development of total quality management in Qatar" The TQM Magazine 12(3).

[7] Belay, A. M., Helo, P., Takala, J., \& Kasie, F.M., 2011, "Effects of quality management practices and concurrent engineering in business performance", International Journal of Business and Management, 6(3), 45-62.

[8] Nilsson, L., Johnson, M.D., \& Gustafsson, A., 2001, "The impact of quality practices on customer satisfaction and business results: Product versus service organizations", Journal of Quality Management, 6 (2001), 5-27.

[9] Rahman, Z. and Siddiqui, J., 2006, "Exploring total quality management for information systems in India firms: Application and benefits", Business Process Management Journal 12(5).

[10] Rodriquez, C. \& Hemsworth, D., 2005, "A Structural analysis of the impact of quality management practices in purchasing on purchasing and business performance" Total Quality Management and Business Excellence, 16(2), 215-230.

[11] Aydın, A., Ucuncu K., 2010, "The effects of total quality management activities of the enterprises on the employee performance", Int. Journal of Economic \& Administrative Studies, 5, 41-60. http://2012e.igem.org/Team:Arizona State E/Kellogg.

[12] Sadikoglu, E., 2008, "Total Quality Management Practices and Performance", The Business Review, Cambridge, Hollywood 10(2).

[13] Okay, S. \& Akcay, M., 2010, "Factors Affecting Satisfaction Levels of Internal Customers in Turkish Automotive Authorized Services", African Journal of Business Management, 4(18), 3872-3891.

[14] Gotzamani, K.D., G.D. Tsiotras, 2002, "The true motives behind ISO 9000 certification and Their effect on the overall certification benefits and their long term contribution towards TQM", International Journal of Quality, Vol. 19, No. 2, pp. 151-169.

[15] Thomas Y. Choi, 2004, "Simultaneous Consideration of TQM and ISO 9000 on Performance and Motivation: An Empirical Study of Spanish Companies Arizona State University", University of Murcia, Spain.

[16] Michael Shadrack Mangula, 2013, "Effect of Quality Management Systems (ISO 9001) Certification on Organizational Performance in Tanzania: A Case of Manufacturing Industries in Morogoro", Mzumbe University.

[17] Abdullah, M. M. B., Uli, J., 2008, "The influence of soft factors on quality improvement and performance: perceptions from managers", The TQM Journal 20 (5). 